\title{
PENDAFTARAN HAK ATAS MEREK
}

\author{
Asuan \\ Fakultas Hukum Universitas Palembang \\ E-mail: asuan.okay@gmail.com
}

\begin{abstract}
The right to a mark recognized by the Indonesian state is a brand that is a part of intellectual property rights as regulated in Law Number 20 of 2016 concerning Marks and Geographical Indications, which revises Law Number 15 of 2001 concerning Marks which is a problem in research on how to register and protect rights to registered marks according to Number 20 of 2016 concerning Marks and Geographical Indications. This research is a normative legal research which is descriptive, not descriptive. Mark registration submitted by the applicant to the Directorate General of Marks, Ministry of Justice and Human Rights and the approved application (individual or legal entity) will receive a certificate registered in the general register of marks. the right to a registered mark is a legal protection of the exclusive right to use the mark yourself or to give permission to other parties to use the mark within 10 years from the date of receipt of registration and can be extended by the owner/or his legal representative.
\end{abstract}

Keywords: trademark registration

Abstrak

Hak atas merek yang diakui oleh negara Indonesia adalah suatu merek yang merupakan suatu hak bagian dari hak kekayaan intelektual sebagaimana diatur dalam Undang-undang Nomor 20 Tahun 2016 tentang Merek dan Indikasi Geografis, yang merevisi Undang-Undang Nornor 15 Tahun 2001 Tentang Merek yang menjadi permasalahan dalam penelitian bagaimana pendaftaran dan perlindungan hak atas merek terdaftar tesebut menurut Nomor 20 Tahun 2016 tentang Merek dan Indikasi Geografis. Penelitian ini merupakan penelitian hukum nornatif bersifat perskriptif bukan deskriptif. Pendaftaran merek diajukan oleh pemohon kepada Direktorat Jenderal Merek Departemen Kehakiman dan HAM dan permohonan (perorangan atau badan hukum) yang telah disetujui akan mendapat sertifikat merek yang terdaftar dalam daftar umum merek. Perlindungan hak atas merek yang terdaftar adalah perlindungan hukum hak eksklusif untuk menggunakan sendiri merek atau memberikan izin kepada pihak lain untuk menggunakan merek tersebut dalam waktu 10 tahun sejak dari tanggal penerimaan pendaftaran dan dapat perpanjang oleh pemilik/atau kuasa hukumnya.

Kata Kunci: pendaftaran hak merek

\section{PENDAHULUAN}

Pada Salah satu perkembangan yang kuat dan memperoleh perhatian dan kecendrungan yang masih akan berlangsung dimasa yang akan datang adalah semakin meluasnya arus globalisasi baik bidang sosial, ekonomi, budaya maupun bidang-bidang kehidupan lainnya. Perkembangan teknologi informasi dan transportasi telah menjadikan kegiatan disektor perdagangan meningkat secara pesat dan bahkan telah menempatkan dunia sebagai pasar tunggal bersama.

Era perdagangan global hanya dapat dipertahankan jika terdapat iklim persaingan usaha yang sehat. Disini merek memegang peranan yang sangat 
penting yang memerlukan sistem pengaturan yang lebih memadai. Berdasarkan pertimbangan tersebut dan sejalan dengan perjanjian-perjanjian internasional yang telah diratifikasi Indonesia serta pengalaman melaksanakan administrasi merek, diperlukan penyempurnaan Undangundang Merek yaitu Undang-undang Nomor 19 tahun 1992 (lembaran Negara Tahun 1992 Nomor 81) sebagaimana diubah dengan Undangundang Nomor 14 Tahun 1997 (lembaran Negara Tahun 1997 Nomor31) ${ }^{1}$.

Hak ata merek merupakan suatu tanda pembeda atas barang atau jasa bagi suatu perusahaan dengan perusahaan lainnya, sebagai tanda pembeda maka merek dalam satu klasifikasi barang atau jasa tidak boleh memiliki persamaan antara satu sama lain, baik pada keseluruhan maupun pada pokoknya.

Sebagaimana diketetaui bahwa merek ini merupakan sesuatu (gambar atau nama) yang dapat digunakan untuk mengidentifikasi suatu produk barang melalui merek, masyarakat sebagai konsumen akan dengan mudah mengenali suatu produk

1 Adrian Sutedi, Hak Atas Kekayaan Intelektual (Jakarta: Sinar Grafika, 2013). perusahaan tertentu. . Merek biasanya dicantumkan pada barang atau pada barang yang dijual atau dijual atau jasa yang ada di dalam pasaran. ${ }^{2}$

Hak atas merek merupakan suatu hak eksklusif yang diberikan oleh negara kepada pemilik Merek yang terdaftar untuk jangka waktu tertentu dengan menggunakan sendiri Merek tersebut atau memberikan izin kepada pihak lain untuk menggunakannya yang sesuai dengan ketentuan berlaku.

Maka dari itu hak atas merek telah dikenal sejak tahun 1912, yaitu pada saat penjajahan Belanda di Indonesia sebagaimana diatur dalam Reglemen Industrieele Eigendom Tahun 1912 yang dimuat dalam Staatblat 1912 jo. Staatblat 1913 Nomor 214.Reglemen tersebut diganti dengan Undang-undang Nomor 21 Tahun 1961 tentang Merek. Undangundang Nomor 21 Tahun 1961 tentang Merek tersebut diganti dengan Undang-undang Nomor 19 Tahun 1992 tentang Merek dan diubah oleh pemerintah dengan Undang-undang Nomor 14 Tahun 1997 tentang Perubahan atas Undang-undang

${ }^{2}$ Insan Budi Maulana, Ridwan Khairandy dan Nur Jihad, Kapita Selekta Hak KekayaanIntelektual (Yogyakarta: Pusat Studi Hukum UII, 2000). 
Nomor 19 Tahun 1992 tentang Merek.

Di negara kita Undang-undang Merek yang terbaru yaitu Undang-undang Nomor 20 Tahun 2016 tentang Merek dan Indikasi Geografis yang diundangkan pada tanggal 25 November 2016 seiring dengan telah diratifikasinya Konvensi Pembentukan World Trade Organization (WTO). Undang-undang ini menggantikan Undang-undang Nomor 19 Tahun 1992 tentang Merek atas perubahan undang-undang tenteng merek yaitu Undangundang Nomor 15 Tahun 2001 atas perubahan Undang- undang Nomor 14 Tahun 1997 tentang Perubahan atas Undang-undang Nomor 19 Tahun 1992 tentang Merek.

Dari uraian diatas bahwa hak atas merek itu dapat memberikan pelayanan bagi para pengusaha atau pedagang agar dalam mengembangkan usahanya, mereka memperoleh perlindungan hukum atas tenaga, pikiran, waktu dan biaya yang telah mereka korbankan dalam rangka membangun suatu reputasi perusahaan dalam wujud merek. Adanya pengaturan tentang merek diharapkan dapat mencegah terjadinya persaingan usaha curang atau tidak sehat.

Hak atas merek ini untuk memperjelas suatu produk barang atau jasa sejenis dapat dibedakan asal muasalnya, kualitasnya, serta serta keterjaminan bahwa produk itu original. Hal ini dijelaskan dalam konsiderans Undangundang Nomor 20 Tahun 2016 tentang Merek dan Indikasi Geografis serta bagian menimbang butir a yang berbunyi :

Bahwa di dalam era perdagangan global, sejalan dengan konvensi internasional yang telah diratifikasi Indonesia, peranan Merek dan Indikasi Geografis menjadi sangat penting terutama dalam menjaga persaingan usaha yang sehat, berkeadilan, pelindungan konsumen, serta pelindungan Usaha Mikro, Kecil, dan Menengah dan industri dalam negeri. ${ }^{3}$

Dalam Undang-undang Nomor 20 Tahun 2016 tentang Merek dan Indikasi Geogarafis yang disebut merek secara lebih detail yaitu dalam Pasal 1 angka 1 yang berbunyi sebagai berikut: Merek adalah tanda yang dapat ditampilkan secara grafis

\footnotetext{
${ }^{3}$ H. OK. Saidin, 2004, Aspek Hukum Hak Kekayaan Intelektual (Intellectual Property Rights) (,Jakarta: PT RajaGrafindo Persada).
} 
berupa gambar, logo, nama, kata, huruf, angka, susunan warna, dalam bentuk 2 (dua) dimensi dan/atau 3 (tiga) dimensi, suara, hologram, atau kombinasi dari 2 (dua) atau lebih unsur tersebut untuk membedakan barang dan/atau jasa yang diproduksi oleh orang atau badan hukum dalam kegiatan perdagangan barang dan/atau jasa. ${ }^{4}$

Hak atas merek ini memiliki unsur pembeda (capable of distinguishing) karena pendaftaran merek tersebut mengkaitkan pemberian monopoli atas nama atau simbol (atau dalam bentuk lain). Agar mempunyai daya pembeda, merek harus dapat memberikan penentuan pada barang atau jasa yang bersangkutan. Para pejabat hukum di seluruh dunia enggan memberikan pelaku dagang hak eksklusif atas suatu merek. Keengganan ini disebabkan pemberian hak eksklusif tadi akan menghalangi orang lain untuk menggunakan merek tersebut. Oleh karena itu, suatu merek harus dapat membedakan

\footnotetext{
${ }^{4}$ Republik Indonesia, Undang-undang HAKI Hak atas Kekayaan Intelektual (Jakarta: Sinar Grafika, 2003).
}

barang atau jasa si pelaku dagang tersebut dari barang atau jasa pelaku dagang lain di bidang yang sama.

$$
\text { Undang-undang Nomor } 20
$$

Tahun 2016 tentang Merek dan Indikasi Geografis pada Pasal 3 menyebutkan bahwa hak atas merek adalah Hak atas Merek diperoleh setelah Merek tersebut terdaftar. Berbeda dengan hak cipta, merek harus didaftarkan terlebih dahulu di dalam Daftar Umum Merek. ${ }^{5}$

Produsen atau pengusaha atau pedagang harus mempunyai jaminan perlindungan hukum terhadap hak atas merek barang dagangannya, Undangundang Nomor 20 Tahun 2016 tentang Merek dan Indikasi Geografis mewajibkan merek tersebut didaftarkan. Dengan terdaftarnya merek sebagaimana dimaksud dalam Pasal 3 Undang-undang tersebut, barulah pemegang merek akan diakui atas kepemilikan merek produk dagangannya.

Prinsip yang dianut dalam Undang-undang Merek Indonesia, yakni first to file principle, bukan first come, first out principle. Berdasarkan prinsip " first to file principle”, maka seseorang yang ingin memiliki hak atas

\footnotetext{
${ }^{5}$ Republik Indonesia
} 
merek harus melakukan pendaftaran atas merek yang bersangkutan dan kuasa hukumnya. Objek atas merek adalah karya-karya seseorang yang berupa tanda, baik tulisan, gambar, kombinasi tulisan dan gambar yang diciptakan dengan tujuan untuk membedakan barang yang satu dengan yang lain tetapi yang sejenis.

Hak atas merek mempunyai berfungsi sebagai tanda pengenal untuk membedakan hasil produksi yang dihasilkan seseorang atau beberapa orang secara bersama-sama atau badan hukum dengan produksi orang lain atau badan hukum lainnya; sebagai alat promosi sehingga dalam mempromosikan hasil produksinya cukup dengan menyebut mereknya; sebagai jaminan atas mutu barangnya; menunjukkan asal barang atau jasa yang dihasilkan.

Hak atas merek akan menampilkan suatu wujud reputasi (goodwill) yang bernilai moral, material, dan komersial.Reputasi (goodwill) yang melekat pada merek merupakan suatu bentuk hak milik (as a from of property). Reputasi (goodwill) dalam dunia usaha yang dipandang sebagai kunci bagi sukses atau tidaknya suatu bisnis dimana banyak pengusaha yang berlomba-lomba untuk memupuk ataupun menjaga reputasinya dengan menjaga kualitas produk dan memberikan pelayanan yang terbaik bagi konsumen.

Bagi para pedagang atau pengusaha, merek merupakan salah satu media untuk memperoleh reputasi baik (goodwill) dan kepercayaan dari konsumen. Selain itu, perusahaan pencetus merek tersebut dapat membangun hubungan antara reputasi (goodwill) tersebut dengan merek yang telah dipakai oleh perusahaan tersebut. Apabila suatu produk tidak memiliki merek, tentu produk tersebut tidak akan dikenal oleh konsumen.

Bahwa hak atas merek secara langsung maupun tidak langsung akan mewakili kualitas, imej, atau reputasi suatu produk. Oleh karena itu, merek mempunyai posisi penting bagi berkembangnya usaha atau bisnis para pedagang atau pengusaha.

Hak atas merek merupakan salah satu bentuk karya intelektual yang mempunyai peran yang sangat penting dalam kehidupan ekonomi, terutama di bidang perdagangan dan jasa, khususnya untuk membedakan dengan produk lain yang sejenis maupun yang tidak sejenis. 
Reputasi suatu hak atas merek yang disebut (goodwill) adalah benda yang tidak berwujud (intangible), secara hukum dipandang sebagai suatu harta atau kekayaan yang harus dilindungi. Merek itu dikonstruksikan sebagai salah satu bagian dari Hak Milik Industri (Industrial Property Rights) yang pengaturannya terdapat dalam ilmu hukum dan dinamakan hukum Hak Kekayaan Intelektual (HKI).

Hak Kekayaan Intelektual (HKI) merupakan suatu bidang hukum yang membidangi hak- hak yuridis dari karya-karya atau ucapan-ucapan hasil olah pikir manusia. Bidanyang dicakup Hak Kekayaan Intelektual (HKI) cukup luas, termasuk di dalamnya semua kekayaan intelektual yang terdiri dari hak cipta (copyright) yang terdiri atas ciptaan, sastra, seni, dan ilmu pengetahuan serta hak milik industrial (industrial property right) yang terdiri atas paten, merek, desain industri, rahasia dagang, dan desain rangkaian listrik terpadu. ${ }^{6}$

Hak atas merek sangat penting baik dalam dunia periklanan dan pemasaran. Oleh karena itu, maka

${ }^{6}$ Budi Agus Riswandi dan M. Syamsudin, Hak Kekayaan Intelektual dan Budaya Hukum (Jakarta: PT RajaGrafindo Persada, 2004). suatu produk yang dipasarkan akan lebih mudah dikenal oleh masayarakat atau konsumen bila dilekati dengan suatu merek yang merupakan ciri dari produk yang dijual tersebut. ${ }^{7}$

Selain itu, apabila produsen barang tersebut ingin agar merek yang diciptakannya terhindar dari pihak lain yang berperilaku curang terhadap merek dagangannya, maka merek tersebut harus didaftarkan dalam Daftar Umum Merek. Dengan terdaftarnya suatu merek dalam Daftar Umum Merek, maka pemilik merek akan memperoleh hak atas merek yang bersifat ekslusif dari negara. Hukum merek berfungsi melindungi kepentingan pemilik merek atau goodwill tersebut dari pihak lain yang hendak mengambil keuntungan dengan cara tidak jujur (unfair competition). Dengan adanya Undang-undang Nomor 20 Tahun 2016 tentang Merek dan Indikasi Geografis diharapkan dapat memenuhi kebutuhan para pedagang atau pengusaha atas adanya perlindungan terhadap hak kekayaan intelektual (dalam hal ini hak atas merek) untuk memproduksi barang atau jasa sebagai komoditi dagang.

${ }^{7}$ Budi Agus Riswandi 
Asuan, Pendaftaran Hak Atas Merek, Halaman 135-160

Undang-undang Nomor 20

Tahun 2016 tentang Merek dan Indikasi Geografis berlaku sejak diundangkannya pada tanggal 20 November 2016, namun tidak semua produsen atau pedagang yang memiliki hak atas merek atas produk dagangannya melakukan pendaftaran.

Apabila produsen barang tersebut memiliki hak atas merek yang diciptakannya terhindar dari konflik dan sengketa tersebut, maka hak atas merek tersebut harus didaftarkan dalam Daftar Umum Merek.

Dengan terdaftarnya suatu merek dalam Daftar Umum Merek, maka pemilik merek akan memperoleh perlindungan atas merek atau hak atas merek yang bersifat eksklusif dari negara. Untuk jangka waktu tertentu dia menggunakan sendiri merek tersebut atau memberi izin kepada seseorang, beberapa orang secara bersama-sama, atau badan hukum untuk menggunakannya. Sedangkan, perlindungan terhadap merek terdaftar yaitu adanya kepastian hukum atas merek terdaftar, baik untuk digunakan, diperpanjang, dialihkan, dan dihapuskan sebagai alat bukti bila terjadi sengketa pelanggaran atas merek terdaftar.

Perlindungan hak atas merek merupakan salah satu aspek penting dalam hukum merek. Perlindungan yang diberikan oleh Undang-undang merek terhadap merek merupakan pengakuan terhadap keberhasilan pemilik merek dalam menciptakan image eksklusif dari produknya yang diperoleh melalui pengiklanan penjualan produk-produknya secara langsung.

Uraian tersebut diatas untuk dapat dijadikan permasalahan yaitu bagaimana Pendaftaran Merek Hak Atas dan Perlindungan Hukum Hak Atas Merek Menurut Undang-Undang Nomor 20 tahun 2016 Tentang Merek Dan Indikasi Geografis.

Dalam penelitian hukum normatif atau penelitian hukum doktrinal (bersifat perskriptif bukan deskriptif). Sumber penelitian yang berupa bahan hukum primer merupakan bahan hukum yang mengikat seperti peraturan perundang- undangan (UndangUndang Nomor 20 Tahun 2016 tentang Merek dan Indikasi Geografis, Kitab Undang-Undang Hukum Perdata) dan putusan hakim. Bahan hukum sekunder yang tidak 
Asuan, Pendaftaran Hak Atas Merek, Halaman 135-160

mengikat seperti hasil/pemikiaran para pakar hukum serta bahan hukum tersier (kamus hukum, ensiklopedia, dan sebagainya).

\section{PEMBAHASAN}

\section{A. Pendaftaran Hak Atas Merek}

Hak atas merek yang merupakan sebagai hak ekslusif karena hak tersebut merupakan hak yang sangat pribadi bagi pemiliknya dan diberi hak untuk menggunakan sendiri atau memberi izin kepada oranglain untuk menggunakan sebagaimana ia sendiri menggunakannya.

Sebagaimana dijelaskan dalam Undang-Undang No. 20 Tahun 2016 Tentang Merek dan Indikasi Geografis berisi mengenai hak eksklusif yang diberikan oleh Negara kepada pemilik Merek yang terdaftar dalam Daftar Umum Merek untuk jangka waktu tertentu dengan menggunakan sendiri merek tersebut atau memberikan izin kepada pihak lain untuk menggunakannya. Tujuan dari mendaftarkan merek tersebut adalah agar tidak terdapat persamaan pada pokoknya atau keseluruhan dengan merek lain yang sudah lebih dulu terdaftar, khusunya merek terkenal. Dalam hal pendaftaran merek melibatkan dua pihak, yaitu pemohon dan pemerintah (Direktorat Jenderal Hak Kekayaan Intelektual).

Pemohon mempunyai peran sebagai pihak yang diwajibkan mendaftarkan hak atas merek tersebut bertujuan agar produk yang didaftarkan tidak mempunyai kesamaan dengan produk lain yang sudah didaftarkan sebelumnya. Sedangkan peran Pemerintah adalah untuk mengabulkan pemohon pendaftaran merek dari pemohon agar merek yang didaftarkan dapat segera diterbitkan, dan apabila merek yang didaftarkan sudah kesamaan dengan merek yang sudah terdaftar terlebih dahulu maka Pemerintah berhak untuk menolak permohonan pendaftran merek itu, dengan begitu pihak yang akan mendaftarkan mereknya tidak bisa mendapatkan perlindungan hukum dikarenakan sudah ada yang mendaftarkan ke Direktorat Jenderal (Direktorat Jenderal Hak Kekayaan Intelektual).

Pada Pasal 3 Undang-Undang Nomor 20 Tahun 2016 tentang Merek dan Indikasi Geografis menyebutkan bahwa hak atas Merek diperoleh setelah Merek tersebut 
terdaftar. Pasal inilah melandasi pentingnya seseorang melakukan pendaftaran atas hak merek yang dimilikinya, guna memperoleh kekuatan hukum dan perlindungan hukum atasnya. Agar pemilik merek memperoleh hak ekslusif atas merek dan mendapat perlindungan hukum, maka pemilik merek yang beritikad baik (prinsip itikad baik) dapat mendaftarkan mereknya kepada pemerintah,. menurut Munir Fuady suatu merek tidak dapat didaftarkan manakala mengandung unsur-unsur sebagai berikut:

1. Hak atas merek tersebut bertentangan dengan perundang-undangan yang berlaku.

2. Merek tidak memiliki daya pembeda.

3. Telah menjadi milik umum.

4. Merupakan keterangan atau berkaitan dengan barang atau jasa yang dimohonkan pendaftarannya.

5. Mempunyai persamaan pada pokoknya atau keseluruhannya dengan merek milik orang lain yang sudah terlebih dahulu terdaftar untuk barang dan/jasa sejenis.

Mempunyai persaman pada pokoknya atau keseluruhannya dengan merek yang sudah terkenal milik pihak lain untuk barang dan atau jasa sejenis.

6. Mempunyai persamaan pada pokoknya atau keseluruhanya dengan indikasi geografis yang sudah terkenal.

7. Merupakan atau menyerupai nama orang terkenal, foto, atau nama badan hukum yang dimiliki orang lain, kecuali atas persetujuan tertulis dari yang berhak.

8. Merupakan tiruan atau menyerupai nama atau singakatan nama, bendera, lambang atau simbol atau emblem negara atau lembaga nasional maupun internasional, kecuali atas persetujuan tertulis dari pihak yang berwenang.

9. Merupakan tiruan atau menyerupai tanda atau cap atau stempel resmi yang digunakan oleh negara atau lembaga pemerintah, kecuali atas persetujuan tertu lis dari pihak yang berwenang. ${ }^{8}$

Dalam hal pendaftaran hak atas merek hanya dapat diajukan untuk satu kelas barang atau jasa. Kelas barang atau jasa dalam kelompok jenis barang atau jasa yang mempunyai persamaan dalam sifat, cara pembuatan, dan tujuan

\footnotetext{
8 Munir Fuady, Pengantar Hukum Bisni (Bandung:: PT. Citra Aditya Bakti, 2012).
} 
penggunaannya. Apabila merek akan dimintakan pendaftarannya untuk lebih dari satu kelas, maka pendaftarannya harus diajukan secara terpisah oleh pemilik hak atas merek. ${ }^{9}$

Berdasarkan uraian diatas bahwa pengertian merek menurut Undang-Undang Merek yang telah dijabarkan sebelumnya, ada 2 (dua) hal atau pembahasan pokok yang dapat dipetik/pahami. Pertama terkait bentuk-bentuk merek yang dapat dipergunakan oleh seseorang atau beberapa orang secara bersama-sama atau badan hukum.

Melalui pengertian merek, disebutkan ada beberapa jenis merek, yang kemudian di jelaskan dalam Pasal 1 angka 2, 3 dan 4 dari Undang-Undang Nomor 15 Tahun 2001 yang sekarang telah diubah dengan Undang-Undang Nomor 20 Tahun 2016 tentang Merek dan Merek dan Indikasi Geografis yang sebagai berikut:

1. Merek dagang adalah merek yang digunakan pada barang yang diperdagangkan oleh seseorang atau beberapa orang

${ }^{9}$ Richard Burton Simatupang., Aspek Hukum Dalam Bisnis (Edisi Revisi) (Jakarta: PT. Rineka Cipta, 2003). secara bersama-sama atau badan hukum membedakan dengan barang-barang sejenis lainnya.

2. Merek jasa adalah merek yang digunakan pada jasa yang diperdagangkan oleh seseorang atau beberapa orang secara bersama- sama atau badan hukum untuk membedakan dengan jasa-jasa sejenis lainnya

3. Merek Kolektif adalah Merek yang digunakan pada barang danjatau jasa dengan karakteristik yang sama mengenai sifat, ciri umum, dan mutu barang atau jasa serta pengawasannya yang akan diperdagangkan oleh beberapa orang atau badan hukum secara bersama-sama untuk membedakan dengan barang dan/atau jasa-jasa sejenis lainnya..

Setelah mengetahui dan memahami jenis-jenis merek dan memahami bahwa pendaftaran hak atas merek merupakan bagian dari prinsip itikad baik yang dipraktekkan dalam kegiatan usaha, begitu juga sebaliknya prinsip itikad baik harus dikedepankan 
Asuan, Pendaftaran Hak Atas Merek, Halaman 135-160

ketika seseorang atau badan usaha ingin mengukuhkan hak atas merek miliknya menjadi terdaftar secara hukum. Selanjutnya akan dijabarkan Langkahlangkah/mekanisme dari proses pendaftaran hak merek yang berdasarkan prinsip itikad baik, mulai dari perm ohonan, pemeriksaan, pengumuman sampai keluartnya sertifikat hak merek terdaftar atas nama pemegang merek yang sah.

\section{Permohonan}

Pada permohonan pendaftaran hak atas merek dapat diajukan secara tertulis, dengan menggunakan bahasa Indoenesia kepada Menteri melalui Direktorat Jenderal HAKI, sebelumnya diatur di dalam Pasal 7 sampai dengan Pasal 10 Undang Undang Nomor 15 Tahun 2001 tentang Merek, namun sekarang telah diubah dengan undang-undang terbaru, dalam hal pendaftaran hak atas merek itu secara tegas di sebutkan dalam Pasal 4 ayat (1) dan ayat (2) Undang-Undang Nomor 20 Tahun 2016, yaitu:

1. Permohonan pendaftaran hak atas merek diajukan oleh Pemohon atau Kuasanya kepada Meriteri secara elektronik atau nonelektronik dalam bahasa Indonesia.

2. Dalam Permohonan sebagaimana dimaksud pada ayat (1) harus mencantumkan:

a. Tanggal, bulan, dan tahun Permohonan;

b. Nama lengkap, kewarganegaraan, dan alamat Pemohon;

c. Nama lengkap dan alamat Kuasa jika Permohonan diajukan melaluiKuasa;

d. Nama jika Merek yang dimohonkan pendaftarannya menggunakan unsur wama;

e. Nama negara dan tanggal permintaan Merek yang pertama kali dalam hal Permohonan diajukan dengan Hak Prioritas; dan

f. Kelas barang dari/atau kelas jasa serta uraian jenis barang dan/atau jenis jasa.

Dalam hal permohonan pendaftaran hak atas merek harus diajukan secara tertulis dalam bahasa Indonesia kepada Direktorat Jenderal Hak Kekayaan Intelektual, oleh pemohon atau kuasa, dengan melampirkan bukti pembayaran biaya 
Asuan, Pendaftaran Hak Atas Merek, Halaman 135-160

pendaftaran Merek. ${ }^{10}$ Dalam surat permohonan harus dicantumkan halhal sebagaimana ketentuan Pasal 4 ayat (2) Undang-Undang Nomor 20 Tahun 2016.

Pemohon dapat dilakukan oleh satu orang atau beberapa secara bersama• sama, atau badan hukum. Dalam hal permohonan diajukan oleh beberapa orang yang sama-sama berhak atas merek tersebut, dengan begitu:

a. Semua nama pemohon harus dicantumkan dalam surat permohonan dengan memilih salah satu alamat sebagai alamat mereka;

b. Surat permohonan pendaftaran harus ditandatangani oleh salah satu dari pemohon yang berhak atas merek tersebut dengan melampirkan persetujuan tertulis dari para pemohon yang mewakilkan, dan;

c. Apabila permohonan pendaftaran dilakukan oleh seorang Kuasa, surat kuasa harus ditandatangani

${ }^{10}$ Zaeni Asyhadie, Hukum Bisnis: Prinsip dan Pelaksanaannya di Indonesia. (Jakarta: PT. RajaGrafindo Persada, 2014). oleh semua pihak yang berhak atas merek tersebut. ${ }^{11}$

\section{Pemeriksaan}

Dalam pemeriksaan terhadap kelengkapan persyaratan permohonan pendaftaran hak atas merek akan dilakukan oleh Direktorat Jenderal. Jika temyata terdapat kekurangan, Direktorat Jenderal akan meminta untuk melengkapinya dalam jangka waktu dua bulan terhitung sejak tanggal pengiriman. Bila jangka waktu terlampaui, dan pihak pemohon tidak melengkapinya maka pengajuan permohonan pendaftaran dianggap ditarik kembali, sedangkan biaya yang sudah dikeluarkan tidak dapat ditarik kembali. Sebaliknya jika persyaratan dianggap lengkap maka Direktorat Jenderal akan diberikan tanggal penerimaan pada surat permohonan. Selanjutnya dalam jangka waktu paling lama tiga puluh hari sejak tanggal penerimaan

\footnotetext{
${ }^{11}$ Saidin OK, Aspek Hukum Hak Kekayaan Intelektual (Intellectual Property Rights),
} (Jakarta: Rajawali Press, 2015). 
Asuan, Pendaftaran Hak Atas Merek, Halaman 135-160

Direktorat Jenderal akan

Pemohon diberitahukan agar menyerahkan permohonan kelengkapan persyaratan pendaftaran kepada pemeriksa untuk dilakukan pemeriksaan secara riil atau nyata. (substantive) $^{12}$.

Dalam hal pemeriksaan merupakan kelengkapan persyaratan Pendaftaran Merek dijelaskan dalam ketentuan Pasal 11 Undang-Undang Nomor 20 Tahun 2016 tentang Merek dan Indikasi Geografis, yang menyatakan :

1. Permohonan hak atas merek diajukan dengan memenuhi semua kelengkapan persyaratan pendaftaran Merek sebagaimana dimaksud dalam Pasal 4, Pasal 5, Pasal 6, Pasal 7, Pasal 9, dan Pasal 10.

2. Dalam hal terdapat kekurangan kelengkapan persyaratan sebagaimana dimaksud dalam Pasal 4, Pasal 5, Pasal 6, darr/atau Pasal 7, dalam jangka waktu paling lama 30 (tiga puluh) Hari sejak tanggal penerimaan, kepada

${ }^{12}$ Zaeni Asyhadie, Hukum Bisnis: Prinsip dan Pelaksanaannya di Indonesia 
Asuan, Pendaftaran Hak Atas Merek, Halaman 135-160

jangka waktu pemenuhan

kelengkapan persyaratan

dimaksud.

\begin{tabular}{lcr}
\multicolumn{2}{c}{ Pemeriksa } & adalah \\
pejabat & yang & karena \\
keahliannya & diangkat & dan \\
diberhentikan & sebagai & pejabat \\
fungsional & oleh & Menteri.
\end{tabular}

Sedangkan pemeriksaan riil atau

substantif maksudnya adalah

suatu pemeriksaan yang

menyangkut

apakah

permohonan pendaftaran merek

tersebut termasuk merek yang

tidak dapat didaftarkan dan

termasuk permohonan yang

tidak memenuhi persyaratan

kelengkapan pendaftaran hak

atas merek harus ditolak atau

tidak diterima.

Pasal 21 ayat (1), (2) dan

(3) Undang-Undang Nomor 20

Tahun 2016 tentang Merek dan

Indikasi Geografis menerangkan

terkait merek yang dapat

dilakukan penolakan terhadap

pendaftarannya, yaitu sebagai

berikut:

1. Perrnohonan ditolak jika

Merek tersebut mernpunyai persamaan pada pokoknya atau keseluruhannya dengan: :

a. Merek terdaftar milik pihak lain atau dimohonkan lebih dahulu oleh pihak lain untuk barang dan atau jasa sejenis;

b. Merek terkenal milik pihak lain untuk barang dari/atau jasa sejenis;

c. Merek terkenal milik pihak lain untuk barang darr/atau jasa tidak sejenis yang memenuhi persyaratan tertentu; atau dan Indikasi Geografis terdaftar

2. Permohonan ditolak jika Merek tersebut :

a. Merupakan atau menyerupai nama atau singkatan nama orang terkenal, foto, atau nama badan hukum yang dimiliki orang lain, kecuali atas persetujuan tertulis dari yang berhak;

b. Merupakan tiruan atau menyerupai nama atau singkatan nama, bendera, 
Asuan, Pendaftaran Hak Atas Merek, Halaman 135-160

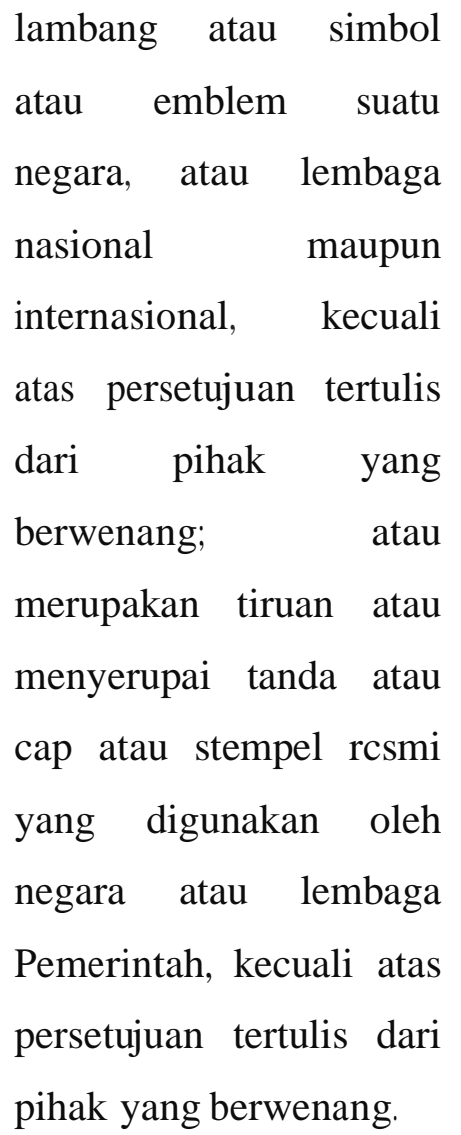

Pada permohonan ditolak jika diajukan oleh Pemohon yang beriktikad tidak baik. Selanjutnya dapat dikemukakan, bahwa jika pemeriksa melaporkan hasil pemeriksaannya tidak dapat didaftar atau ditolak, maka atas persetujuan Direktorat Jenderal hal tersebut harus diberitahukan secara tertulis kepada pemohon dan kuasanya dengan menyebutkan alasanalasannya. Pemohon atau kausanya dalam jangka waktu tiga puluh hari dapat menyampaikan keberatan atau tanggapan atas penolakan tersebut dengan mengemukakan alasan. Jika tanggapan dan keberatan pemohon atau kuasanya diterima, pengumuman merek akan dilakukan, sebaliknya jika tidak diterima, atas persetujuan Direktorat Jenderal akan ditetapkan Surat Keputusan tentang penolakan permohonan pendaftaran $^{13}$.

Terhadap penolakan permohonan merek, dapat diajukan permohonan banding kepada Komisi Banding Merek sebagai badan yang independen dilingkungan Departemen Kehakiman dan HAM. Komisi ini akan membentuk suatu majelis yang akan memeriksa permohonan banding yang telah diajukan. Dala hal Komisi Banding menolak permohonan banding, pemohon banding dapat mengajukan gugatan atas putusan penolakan tersebut kepada Pengadilan Niaga

${ }^{13}$ Riswandi. Budi Agus dan M. Syamsuddin Hak Kekayaan Intelektual dan Budaya Hukum (Jakarta: PT. RajaGrafindo Persada, 2004). 
Asuan, Pendaftaran Hak Atas Merek, Halaman 135-160

dalam waktu paling lama 3

(tiga) bulan terhitung sejak tanggal diterimanya keputusan penolakan tersebut. Selanjutnya atas putusan Pengadilan Niaga hanya dapat diajukan Kasasi Mahkamah Agung. ${ }^{14}$

\section{Pengumuman}

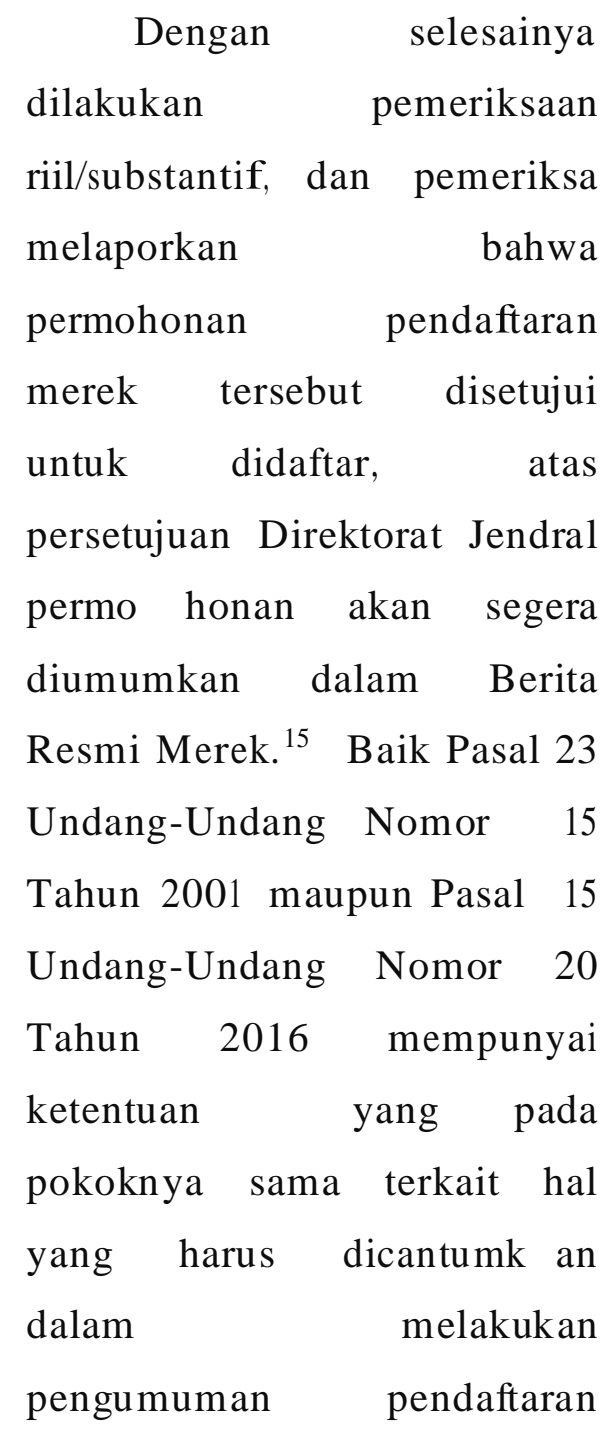

14 Prodjohamidjojo Martiman, Penerapan Pembuktian Terbalik Dalam Kasus Korupsi (Bandung: Mandar Maju, 2010).

${ }^{15}$ Zaeni Asyhadie, Hukum Bisnis: Prinsip dan Pelaksanaannya di Indonesia merek. Pengumuman dilakukan dengan mencatumk an:

a. Nama dan alamat lengkap Pemohon, termasuk Kuasa jika Permohonan diajukan melalui Kuasa;

b. Kelas dan jenis barang dan/atau jasa;

c. Tanggal Penerimaan;

d. Nama negara dan tanggal penerimaan perm ohonan yang pertama kali, dalam hal Permohonan diajukan dengan menggunakan Hak Prioritas; dan

e. Label Merek, term asuk keterangan mengenai wama dan apabila etiket Merek menggunakan bahasa asing dan/atau huruf selain huruf Latin dan/atau angka yang tidak lazim digunakan dalam bahasa Indonesia, disertai terjemahannya ke dalam bahasa Indonesia, huruf Latin atau angka yang lazim digunakan dalam bahasa Indonesia, serta cara pengucapannya dalam ejaan latin. 


Menurut ketentuan
Undang-Undang Nomor 15
Tahun 2001 tentang Merek
masih terkait perm ohonan
pendaftaran hak atas merek,
selanjutnya dalam waktu 10
(sepuluh) hari terhitung
sejak tanggal disetujuinya
permohonan untuk didaftar,
Ditjen HAKI akan
mengumumkan permohonan tersebut dalam Berita Resmi Merek. Pengumuman tersebut akan berlangsung selama 3 (tiga) bulan yang dilakukan dengan menempatkannya dalam Berita Resmi Merek yang diterbitkan secara berkala, atau dengan menempatkannya pada sarana khusus yang dengan sudah serta jelas dapat dilihat oleh masyarakat misalnya internet. ${ }^{16}$ Dari uraian itu saat sekarang ini telah diubah dalam undangundang merek yang baru pada Pasal 14 UndangUndang Nomor 20 Tahun 2016 tentang Merek dan

${ }^{16}$ Richard Burton Simatupang, Aspek Hukum Dalam Bisnis
Indikasi Geografis, yang menyebutkan :

1. Menteri mengumumkan Permohonan dalam Berita Resmi Merek dalam waktu paling lama 15 (lima belas) Hari terhitung sejak Tanggal Penerimaan Perm ohonan sebagaimana dimaksud dalam Pasal 13.

2. Pengumuman

Permohonan dalam Berita Resmi Merek sebagaimana dimaksud pada ayat (1) berlangsung selama 2 (dua) bulan.

3. Berita Resmi Merek sebagaimana dimaksud pada ayat (2) diterbitkan secara berkala oleh Menteri melalui sarana elektronik dan/atau non• elektronik.

Dalam hal pengumuman pendaftaran hak atas merek itu telah diubah dengan undang• undang yang baru baik dari sisi jangka waktu pengumuman maupun dari sisi sarana pengemuman baik itu sarana elektronik dan/atau non-elektronik. Oleh karenanya pada saat sekarang 
Asuan, Pendaftaran Hak Atas Merek, Halaman 135-160

ini jika ingin melakukan permohonan pendaftaran hak atas merek dengan dasar hukumnya ialah Undang-Undang Nomor 20 Tahun 2016 tentang Merek dan Indikasi Geografis.

Mengenai jangka waktu pengumuman merek dalam Berita Acara Resmi Merek, setiap pihak (pemohon atau kuasanya) dapat mengajukan tentang keberatan secara tertulis kepada Direktorat Jenderal atas Perm ohonan Pendaftaran Merek tersebut dengan dikenai biaya. Dalam jangka waktu 14 (empat belas) hari sejak diterimanya keberatan, Direktorat Jenderal harus mengirirnkan salinan surat keberatan kepada pemohon dan kuasanya. Pemohon atau kuasanya harus membalasa surat atas keberatan dengan sautu sanggahan kepada Direktorat Jenderal dalam jangka waktu paling lama 2 (dua) bulan (Pasal 16 Undang-Undang tentang Merek dan Indikasi Geografis). Mengenai sanggahan dan keberatan yang baru langsung disampaikan kepada pihak kementrian terkait yang disebutkan dalam pasal 17 ayat (1) Undang-Undang No. 21 tahun 2016 tentang Merek dan Indikasi Geografis.

Menurut uraiaan diatas bahwa keberatan dan sanggahan tersebut atas Direktorat Jenderal memerintahkan kepada pemeriksa untuk mengadakan pemeriksaan kembali atas permohonan pendaftaran merek. Jika hasil pemeriksaan kembali menyatakan bahwa keberatan diterima maka perm ohonan pendaftaran merek ditolak. Sebaliknya jika keberatannya yang ditolak, maka atas persetujuan Direktorat Jendral/Menteri merek tersebut harus didaftar dalam Daftar Umum Merek, Berdasarkan Pasal 19 ayat (1) UU Merek dan Indikasi Indikasi Geografis menyebutkan selama belum diterbitkannya sertifikat Merek atau surat penolakan dari Menteri, Permohonan dapat ditarik kembali oleh Pemohon atau Kuasanya Pada intinya setiap perm ohonan merek diajukan kepada Direktorat Jenderal Merek Departemen Kehakiman dan HAM dan setiap perm ohonan yang telah disetujui akan memperoleh sertifikat merek yang terdaftar dalam daftar umum merek. Perm 
ohonan pendaftaran merek

dilakukan secara tertu lis dalam bahasa Indonesia, yang diajukan oleh pemohon atau kausanya kepada departemen pemerintah yang berwenang. Jika pemohon adalah pemohon dengan perm ohonan yang menggunakan hak prioritas seperti tersebut di atas, harus diajukan dalam waktu paling lama 6 ( enam) bulan terhitung sejak tanggal penerimaan perm ohonan pendaftaran merek yang peratama sekali di terima di negara lain, yang merupakan anggota Paris Convention for the Protection of Industrial Property, atau anggota Agreement Establishing the World Trade Organization. ${ }^{17}$

Menurut penjelasan Pasal 9 Undang-Undang Nomor 20 Tahun 2016 tentang Merek dan Indikasi Geografis.. Berkenaan dengan Perrnohonan perpanjangan pendaftaran Merek, pemilik Merek diberi kesempatan tambahan untuk dapat melakukan perpanjangan pendaftaran Mereknya sampai 6 (enam) bulan setelah berakhimya jangka waktu pendaftaran Merek. Ketentuan ini

17 Elsi Kartika Sari dan Advendi Simangunsong., Hukum Dalam Ekonomi (Jakarta: PT.Gramedia Widiasarana Indonesia, 2007). dimaksudkan agar pemilik Merek terdaftar tidak dengan mudah kehilangan Hak atas Mereknya sebagai akibat adanya keterlambatan dalam mengajukan perpanjangan pendaftaran Merek. ${ }^{18}$ Atas dasar itu proses dari pendaftaran merek harus dipatuhi oleh pihak-pihak yang mempunyai kepentingan dari hak atas merek yang akan didaftarkan tersebut.

Proses awalnya dari permohonan pendaftaran hak atas merek yang intinya pemohon atau kuasa hukumnya harus berdasarkan itikad baik, pemeriksaan, dan pengumuman dilewati oleh pihak pemohon pendaftaran merek dan pada akhimya memenuhi syarat-syarat administratif dan pemeriksaan substantif, sehingga pemohon merek tersebut dinyatakan layak sebagai pemegang merek yang sah. Atas hal itu hak merek yang didaftarkan tersebut terdaftar dan dicantumkan dalam Daftar Umum Merek. Sehingga pantaslah pihak pemohon tersebut dinyatakan sebagai pemegang hak atas merek terdaftar. Disini pemegang hak atas merek terdaftar yang terbukti beritikad baik sudah mendapatkan

\footnotetext{
${ }^{18}$ Penjelasan Atas Undang-Undang No.20 Tahun 2016 Tentang Merek dan Indikasi Geografis.
} 
kekuatan hukum atas mereknya dan diberikan perlindungan hukum dari negara, sebagaimana tanggungjawab negara sebagai negara hukum. Hal itu sebagai pengaplikasian dari teori perlindungan hukum itu sendiri. (Pasal 21 ayat (3) UU No. 16 Tahun 2021 tentang Merek dan Indikasi Geografis).

\section{B. Perlindungan Hukum Hak} Atas Merek

Dimaksud perlindungan hokum merupakan suatu perlindungan yang diberikan terhadap subyek hukum dengan perangkat hukum baik yang bersifat preventif maupun yang bersifat represif, baik yang tertulis maupun tidak tertulis agar dapat memberikan suatu keadilan, ketertiban, kepastian, kemanfaatan dan kedamaian, hal ini yang dimaksudkan tujuan hokum.

Dalam perlindungan hukum bagi masyarakat Indonesian pada umumnya dapatakan dibedakan dua macam, yaitu : perlindungan hukum yang preventif dan perlindungan hukum yang represif. Pada perlindungan hukum yang preventif, kepada rakyat diberikan kesempatan untuk mengajukan keberatan (inspraak) atau pendapatnya sebelum suatu keputusan pemerintah mendapat bentuk yang definitif. ${ }^{19}$

Maka dari itu perlindungan hukum yang preventif bertujuan mencegah terjadinya sengketa sedangkan sebaliknya perlindungan hukum yang represif bertujuan untuk menyelesaikan permasalahan atau sengketa. Perlindungan hukum terhadap hak atas merek merupakan suatu sistem atau cara yang dirancang untuk memberikan perlindungan terhadap pemegang hak atas merek dengan perangkat hukum berupa peraturan perundang- undangan tentang merek, baik yang bersifat preventif maupun yang bersifat represif agar dapat memberikan keadilan, ketertiban, kepastian, kemanfaatan dan kedamaian bagi pemegang hak atas merek. Di Indonesia, perlindungan hak atas merek diatur dalam Undang-Undang No. 20 Tahun 2016 tentang Merek dan Indikasi Geografis.

Dalam Pasal 1 angka 1 undangundang tersebut disebutkan bahwa merek adalah tanda yang dapat ditampilkan secara grafis berupa gambar, logo, nama, kata, huruf, angka, susunan warna, dalam bentuk 2 (dua)

\footnotetext{
${ }^{19}$ Hidayah, Khoirul, Hukum Hak Kekayaan Intelektual (Malang: Setara Press, Malang, 2017).
} 
Asuan, Pendaftaran Hak Atas Merek, Halaman 135-160

dimensi dan/atau 3 (tiga) dimensi, suara, hologram, atau kombinasi dari 2 (dua) atau lebih unsur tersebut untuk membedakan barang dan/atau jasa yang diproduksi oleh orang atau badan hukum dalam kegiatan perdagangan barang dan/atau jasa. Berdasarkan bunyi pasal tersebut, fungsi merek yang utama adalah membedakan barang atau jasa produksi perusahaan lain sejenis. Dengan demikian, merek merupakan tanda pengenal asal barang atau jasa yang bersangkutan dengan produsen dan konsumennya.

Dimaksud dengan merek yang merupakan sebagai tanda pengenal akan dapat menggambarkan jaminan kepribadian (individuality) dan reputasi barang dan jasa hasil usahanya sewaktu diperdagangkan. Dari sisi produsen, merek digunakan sebagai jaminan nilai hasil produksinya, khususnya mengenai kualitas kemudian pemakaiannya. Dari segi pedagang, merek digunakan untuk promosi barang-barang dagangannya guna mencari dan meluaskan pasar. Dari sisi konsumen, merek sangat diperlukan untuk melakukan pililhan barang yang akan dibeli dan untuk perlindungan hukum atas barang tersebut tertera mereknya. ${ }^{20}$

Mengingat hal ini sangat pentingnya arti dan peranan merek dalam dunia industri dan perdagangan, maka seharusnya hak merek yang dimiliki seseorang dilindungi secara yuridis dari perbuatan-perbuatan yang mengarah pada pemakaian merek secara tidak sah atau melanggar hukum. Dengan demikian, diperlukannya perlindungan hukum untuk memproteksi suatu hak merek dari perbuatan yang mengarah pada perbuatan melawan hukum yang dilakukan oleh orang-orang yang tidak bertanggungjawab. Kebutuhan untuk atas perlindungan hokum hak atas merek semakin berkembang pesat setelah banyak pihak melakukan tindak kecurangan, terlebih setelah dunia perdagangan semakin maju dan berkembang pesat. ${ }^{21}$

Dalam perlindungan hukum hak atas merek ditujukan kepada dua kepentingan, yaitu kepentingan pemilik merek (produsen) dan kepentingan pembeli atau pemakai

\footnotetext{
${ }^{20}$ Insan Budi Maulana, Sukses Bisnis melalui Merek, Paten, dan Hak Cipta (Bandung: Aditya Bakti, 1997).

${ }^{21}$ Muhammad Djumhana dan R. Djubaedilah, Hak Milik Intelektual (Sejarah, Teori dan Praktiknya di Indonesia) (Bandung: PT. Citra Aditya Bakti, 2011).
} 
Asuan, Pendaftaran Hak Atas Merek, Halaman 135-160

yang disebut konsumen. Secara menyeluruh, kepentingan-kepentingan yang hendak dilindungi oleh hukum merek dapat dibagi menjadi 4 (empat) kelompok sebagai berikut :

a. Kepentingan bagi pemilik hak atas merek untuk tidak diganggu gugat dalam hubungan baiknya dengan para konsumen, yang telah dibina olehnya di pasar melalui penggunaan suatu merek tertentu, serta dalam harapan yang wajar untuk memperoleh langganan tetap pada masa datang, yang kesemuanya itu terjamin oleh pengenalan masyarakat kepada merek tersebut, yang menunjukkan bahwa pemilik merek itu adalah produsen dari barang yang bersangkutan.

b. Kepentingan bagi para produsen atau para pedagang lainnya yang bersaing untuk bebas memasarkan barangbarangnya dengan memakai tandatanda umum yang dapat dipakai oleh siapa saja, dan yang seharusnya tidak boleh dimonopoli oleh siapa pun sehingga tidak merugikan kebebasan mereka untuk menjual barang-barangnya dalam persaingan jujur dan sah.

c. Kepentingan pihak konsumen untuk dilindungi terhadap praktik-praktik yang cenderung hendak menciptakan kesan-kesan yang dapat menyesatkan dan menipu atau membingungkan mereka, dengan cara memengaruhi pikiran mereka bahwa suatu perusahaan adalah sama dengan perusahaan lain, atau hasil-hasil dari suatu perusahaan itu juga berasal dari perusahaan yang lain tersebut.

d. Kepentingan umum untuk memajukan perdagangan yang yang bersifat jujur, hal ini untuk mencegah timbulnya praktik-praktik yang tidak jujur dan pula bertentangan hukum dan beretentangan dengan norma-norma kepatutan dalam perdagangan. ${ }^{22}$

Untuk mendapatkan suatu perlindungan hukum apabila merek tersebut sudah didaftarkan di Direktorat Jenderal Hak Kekayaan Intelektual. Karena disebutkan dalam perjanjian TRIPs dan di dalam Pasal 1 angka 5 Undang-Undang No. 20 Tahun 2016 tentang Merek dan Indikasi Geografis bahwa pemilik merek yang terdaftar yang memiliki hak eksklusif untuk menggunakan sendiri merek tersebut atau memberikan izin kepada pihak lain untuk menggunakannya. Tujuan memberi hak eksklusif atas merek,

22 Suyud Margono, Hak Milik Industri: Pengaturan dan Praktik di Indonesia (Bogor: Ghalia Indonesia, 2011). 
maupun alasan menyamakan merek sebagai Hak Milik, bermaksud untuk memudahkan pemberian jaminan perlindungan hukum terhadapnya. Adapun yang dimaksud dengan hak khusus yang diberikan negara kepada pemilik merek yang terdaftar meliputi :

a. Menciptakan hak tunggal (sole or single right)

Hukum atau undang-undang memberi hak tersendiri kepada pemilik merek. Hak itu terpisah dan berdiri sendiri secara utuh tanpa campur tangan pihak lain.

b. Mewujudkan hak monopoli (monopoly right)

Siapapun dilarang meniru, memakai, dan mempergunakan dalam perdagangan barang dan jasa tanpa izin pemilik merek.

c. Memberi hak paling unggul (superiror right)

Hak superior merupakan hak yang diberikan doktrin hak paling unggul bagi pendaftar pertama. Oleh karena itu, pemegang hak khusus atas suatu merek menjadi unggul dari merek orang lain untuk dilindungi. ${ }^{23}$

${ }^{23}$ Sudargo Gautama, Hak Merek Dagang Menurut Perjanjian TRIPs-GATT dan Undang-Undang Merek RI (Bandung: Citra Aditya Bakti).
Dari uraian diatas bahwa ruang lingkup perlindungan hukum yang diberikan kepada pemilik merek meliputi penggunaan atau eksploitasi merek mencakup:

1. Melindungi penggunaan hak eksklusif merek meliputi :

a. Mempergunakan tanda merek sebagai logo, label, atau gambar dalam suratmenyurat, pada barang atau jasa, pada kemasan (packaging) dalam advertensi atau promosi.

b. Menikmati secara eksklusif manifestasi yang lahir dari merek meliputi goodwill atau well-known, reputasi tinggi (high reputation), indikasi sumber asal/geografis, sentuhan kultural (cultural attachment), dan sentuhan keakraban (familiar attachment).

2. Melindungi hak eksklusif menggunakan merek sebagai alat eksploitasi memperoleh keuntungan dalam perdagangan, meliputi:

a. Memasarkan barang atau jasa dalam perdagangan nasional, regional, dan global.

c. Menyimpan barang yang dilindungi merek, asal tidak bertentangan dengan ketentuan monopoli atau spekulasi untuk menaikkan harga.

d. Menyuplai barang 
Asuan, Pendaftaran Hak Atas Merek, Halaman 135-160

e. Mengekspor barang

3. Melindungi hak memperluas wilayah dan segmen pemasaran, sesuai dengan sistem pasar atau perdagangan bebas dan dilakukan sesuai dengan prinsip persaingan bebas, jujur, dan sehat.

4. Melindungi pengalihan atau transfer dalam bentuk

a. Transfer berdasarkan titel umum sesuai dengan ketentuan hukum waris

b. Transfer dalam segala bentuk transaksi yanga dibenarkan oleh undangundang (menjual, mengagunkan, menghibahkan)

c. Dalam bentuk lisensi, memberi izin kepada orang lain atau badan hukum untuk menggunakannya. ${ }^{24}$

Menurut Undang-Undang Merek dan Indikasi Geograpis tentang perlindungang hak atas merek yang terdaftar menurut Bagian Keenam Pasal 35 sebagai berikut :

(1) Merek terdaftar mendapat pelindungan hukum untuk jangka waktu 10 (sepuluh) tahun sejak Tanggal Penerimaan.

${ }^{24}$ Firmansyah, Hery, Perlindungan Hukum terhadap Merek, Panduan Memahami Dasar Hukum Penggunaan dan Perlindungan Merek (Yogyakarta: Pustaka Yustisia, 2011).
(2) Jangka waktu pelindungan sebagaimana dimaksud pada ayat (1) dapat diperpanjang untuk jangka waktu yang sama.

(3) Permohonan perpanjangan sebagaimana dimaksud pada ayat (2) diajukan secara elektronik atau nonelektronik dalam bahasa Indonesia oleh pemilik Merek atau Kuasanya dalam jangka waktu 6 (enam) bulan sebelum berakhirnya jangka waktu pelindungan bagi Merek terdaftar tersebut dengan dikenai biaya.

(4) Permohonan perpanjangan sebagaimana dimaksud pada ayat (2) masih dapat diajukan dalam jangka waktu paling lama 6 (enam) bulan setelah berakhirnya jangka waktu pelindungan Merek terdaftar tersebut dengan dikenai biaya dan denda sebesar biaya perpanjangan.

Perlindungan hukum yang harus diberikan dan diterapkan terhadap hak eksklusif sebagai hak milik. Hukum harus dapat memberikan jaminan perlindungan penuh kepada pemilik hak atas merek terdaftar dari pelanggaranpelanggaran hak atas merek yang mengganggu setiap kegiatan pemilik merek terdaftar tersebut. Perlindungan hukum tersebut dapat berupa perlindungan yang bersifat preventif 
maupun represif. Perlindungan hukum yang bersifat preventif dilakukan melalui pendaftaran merek. Sedangkan perlindungan hukum yang bersifat represif dilakukan jika terjadi pelanggaran merek melalui gugatan perdata dan atau tuntutan pidana.

\section{KESIMPULAN DAN}

\section{REKOMENDASI}

Permohonan pendaftaran merek diajukan kepada Direktorat Jenderal Merek Departemen Kehakiman dan HAM dan setiap permohonan (perorangan atau badan hukum) atau kuasa hukumnya yang telah disetujui akan memperoleh sertifikat merek yang terdaftar dalam daftar umum merek yang dijelaskan dalam pasal 3 dan 4 UU No. 16 Tahun 2016 Tentang Merek dan Indikasi Geogarafis.

Pemilik/pemegang hak atas merek yang telah terdaftar Jenderal Merek Departemen Kehakiman dan HAM akan mendapatkan suatu perlindungan hukum hak eksklusif untuk menggunakan sendiri merek atau memberikan izin kepada pihak lain untuk menggunakannya dalam untuk jangka waktu 10 tahun sejak tanggal penerimaan pendaftaran dan dapat perpanjang oleh pemilik/atau kuasa hukumnya (pasal 35 UU Merek dan Indikasi Geografis).

Disarankan pada pemerintah untuk mensosialisasikan tentang pendaftaran merek atas suatu produk kepada masyarakat/pelaku usaha yang menggunakan hak atas merek. Diharapkan agar masyarakat/pelaku usaha untuk meningkatkan kesadaran hukum untuk dapat mendaftarkan hak atas merek serta mendapatkan perlindungan hukum dari pemerintah yang berhubungan atas hak merek tersebut.

\section{DAFTAR PUSTAKA}

Adrian Sutedi, Hak Atas Kekayaan Intelektual ,Jakarta: Sinar Grafika, 2013.

Budi Agus Riswandi dan M. Syamsudin, Hak Kekayaan Intelektual dan Budaya Hukum, Jakarta: PT RajaGrafindo Persada, 2004.

Elsi Kartika Sari dan Advendi Simangunsong., Hukum Dalam Ekonomi, Jakarta: PT.Gramedia Widiasarana Indonesia, 2007.

Firmansyah, Hery, Perlindungan Hukum terhadap Merek, Panduan Memahami Dasar Hukum Penggunaan dan Perlindungan

Merek ,Yogyakarta: Pustaka Yustisia, 2011. 
Hidayah, Khoirul, Hukum Hak

Kekayaan Intelektual, Malang: Setara Press, Malang, 2017.

H. OK. Saidin, 2004, Aspek Hukum Hak Kekayaan Intelektual (Intellectual Property Rights), Jakarta: PT RajaGrafindo Persada.

Insan Budi Maulana, Sukses Bisnis melalui Merek, Paten, dan Hak Cipta, Bandung: Aditya Bakti, 1997.

Insan Budi Maulana, Ridwan Khairandy dan Nur Jihad, Kapita Selekta Hak KekayaanIntelektual, Yogyakarta: Pusat Studi Hukum UII, 2000.

Munir Fuady, Pengantar Hukum Bisnis, Bandung:: PT. Citra Aditya Bakti, 2012.

Muhammad Djumhana dan R. Djubaedilah, Hak Milik Intelektual (Sejarah, Teori dan Praktiknya di Indonesia), Bandung: PT. Citra Aditya Bakti, 2011.

Prodjohamidjojo Martiman,

Penerapan Pembuktian Terbalik

Dalam Kasus Korupsi, Bandung:

Mandar Maju, 2010.

Republik Indonesia, Undang-undang HAKI Hak atas Kekayaan Intelektual, Jakarta: Sinar Grafika, 2003.

Richard Burton Simatupang, Aspek Hukum Dalam Bisnis (Edisi Revisi), Jakarta: PT. Rineka Cipta, 2003.

Riswandi. Budi Agus dan M.

Syamsuddin. Hak Kekayaan Intelektual dan Budaya Hukum,
Jakarta: PT. RajaGrafindo Persada, 2004.

Saidin OK, Aspek Hukum Hak Kekayaan Intelektual (Intellectual Property Rights), Jakarta: Rajawali Press, 2015.

Sudargo Gautama, Hak Merek Dagang Menurut Perjanjian TRIPs-GATT dan UndangUndang Merek RI, Bandung: Citra Aditya Bakti.

Suyud Margono, Hak Milik Industri: Pengaturan dan Praktik di Indonesia, Bogor: Ghalia Indonesia, 2011.

Undang-Undang Nomor 20 Tahun 2016 Tentang Merek dan Indikasi Geografis.

Zaeni Asyhadie, Hukum Bisnis: Prinsip dan Pelaksanaannya di Indonesia, Jakarta: PT. RajaGrafindo Persada, 2014. 